\title{
The Ginkgo biloba Extract Reverses the Renal Effects of Titanium Dioxide Nanoparticles in Adult Male Rats
}

\author{
Carlos Enrique Escárcega-González, ${ }^{1}$ \\ Irma Guadalupe Reynoso-Andeola, ${ }^{1}$ Fernando Jaramillo-Juárez, ${ }^{1}$ \\ Haydée Martínez-Ruvalcaba, ${ }^{2}$ and Francisco A. Posadas del Rio ${ }^{1}$ \\ ${ }^{1}$ Departamento de Fisiología y Farmacología, Centro de Ciencias Básicas, Universidad Autónoma de Aguascalientes, \\ 20131 Aguascalientes, AGS, Mexico \\ ${ }^{2}$ Departamento de Microbiología, Centro de Ciencias Básicas, Universidad Autónoma de Aguascalientes, \\ 20131 Aguascalientes, AGS, Mexico
}

Correspondence should be addressed to Carlos Enrique Escárcega-González; cescarcega@correo.uaa.mx

Received 31 October 2015; Accepted 8 February 2016

Academic Editor: Andrei Surguchov

Copyright (c) 2016 Carlos Enrique Escárcega-González et al. This is an open access article distributed under the Creative Commons Attribution License, which permits unrestricted use, distribution, and reproduction in any medium, provided the original work is properly cited.

The Ginkgo biloba extract (GbE) is a commercial product used as a nutraceutic herbal remedy in Europe and US. It contains $27 \%$ of the polyphenols isorhamnetin, kaempferol, and quercetin, as antioxidants. We used male adult Wistar rats (200-300 g), divided into four groups: control group (treated with $5.0 \mathrm{mg} / \mathrm{kg}$ of sodium chloride, intravenous), titanium dioxide nanoparticles ( $\mathrm{TiO}_{2}-$ $\mathrm{NPs}$ ) group $\left(5.0 \mathrm{mg} / \mathrm{kg}\right.$, intravenous), GbE group $\left(10 \mathrm{mg} / \mathrm{kg}\right.$, intraperitoneal), and $\mathrm{GbE}+\mathrm{TiO}_{2}-\mathrm{NPs}_{\text {group }}$ (treated $24 \mathrm{~h}$ before with $10 \mathrm{mg} / \mathrm{kg}$ of $\mathrm{GbE}$, intraperitoneal), followed, $24 \mathrm{~h}$ later, by $5.0 \mathrm{mg} / \mathrm{kg}$ of $\mathrm{TiO}_{2}-\mathrm{NPs}_{\text {intravenously. The statistical analysis was }}$ performed using Student's $t$-test for grouped data with ANOVA posttest. The $\mathrm{GbE}$ protected renal cells against the effects of $\mathrm{TiO}_{2}-$ NPs because it reversed the increased activity of $\gamma$-glutamyltranspeptidase and the enzymatic activity of dipeptidylaminopeptidase IV at all times tested $(0-5,5-24,24-48$, and $48-72 \mathrm{~h})$. Also it reversed the glucosuria, hypernatriuria, and urine osmolarity at three times tested (5-24, 24-48, and 48-72). Thus, we conclude that GbE has a beneficial activity in the cytoplasmic membranes of brush border cells on the renal tubules, against the adverse effects that can be produced by some xenobiotics in this case the $\mathrm{TiO}_{2}-\mathrm{NPs}_{\text {, }}$ in experimental rats.

\section{Introduction}

The main function of kidneys, in mammals, is the excretion of metabolic end products from the body and the regulation of extracellular fluid volume and electrolyte composition [1]. Their high blood flow, combined with their ability to concentrate solutes, exposes them to high concentration of xenobiotics present in the systemic circulation. Because of the rich blood supply of the kidneys, in relation to their mass, this organ is particularly liable to damage by toxic substances.

Most living organisms are exposed to nanoparticles (NPs) through the gastrointestinal tract, the lungs, and the skin [2-4]. Moreover, titanium dioxide nanoparticles $\left(\mathrm{TiO}_{2}-\mathrm{NPs}\right)$ affect kidney cells in vitro [5-7] and in vivo [8].
Once into the body, the NPs can interact with cell structures like the plasmatic membrane and cause disruption of it. Some of the biological effects of $\mathrm{TiO}_{2}$-NPs in nanomedicine, after intravenous injection, deliver $\mathrm{TiO}_{2}$-NPs into the human body: they induce pathological lesions in liver, spleen, kidneys, and brain [9]. Also, the intravenous administration of $\mathrm{TiO}_{2}$-NPs $(5 \mathrm{mg} / \mathrm{kg})$ in rats causes an accumulation of nanoparticles in the kidneys with the highest burden on a day 1 after exposure and remains until day 14 [10]. Furthermore, after a single oral administration $(5 \mathrm{~g} / \mathrm{kg})$ in mice, these nanoparticles change some serum biochemical parameters (alanine aminotransferase (ALT), aspartate aminotransferase (AST), LDH, and BUN), and pathology of the kidneys indicated that renal injury was induced after exposure [11]. 
One of the first ultrastructural changes seen after treatment with many nephrotoxins is sloughing of proximal tubule brush borders [12]. The enzymes $\gamma$-glutamyltranspeptidase ( $\gamma$-GTP) and dipeptidylaminopeptidase IV (DAP-IV) are predominantly located on the apical membrane (brush border) of proximal cells $[13,14]$. Thus, xenobiotics (in this case $\mathrm{TiO}_{2}$-NPs) can produce release of $\gamma$-GTP and DAP-IV from their site in the brush border membrane of renal tubules, causing their urinary excretion (enzymuria). Moreover, along the nephron, the reabsorption and secretion of solutes (sodium and glucose) are done by different cotransporters such as sodium-glucose sodium-phosphate, sodiumamino, $\mathrm{Na}-\mathrm{K}-2 \mathrm{Cl}$, and $\mathrm{Na}-\mathrm{Cl}$. Therefore, the damage of the cytoplasmic membrane would disrupt the function of these cotransporters. These transporters are the major participants in urine osmolarity [15].

The Ginkgo biloba extract (GbE) is a commercial product, considered as nutraceutic [16] with possible beneficial effects on human health [17-23]. The GbE contains an average of $27 \%$ polyphenols isorhamnetin, kaempferol, and quercetin [24-28] and 6\% terpene lactones (terpenoid fraction). The terpenoid fraction primarily contains ginkgolides $\mathrm{A}, \mathrm{B}, \mathrm{C}$, $\mathrm{J}$, and $\mathrm{M}$, as well as bilobalide. Its purported biological effects include free radical scavenging, antiapoptotic, antiinflammatory, and antioxidative activities [29]. The GbE is used in many applications such as the treatment of dementia, cerebral insufficiency, or related cognitive decline [30]. The possible mechanisms implied in the neuroprotective effect are modulation of ion homeostasis, glucocorticoid levels, and synthesis of growth factors [31]. In recent clinical and experimental experiments, $\mathrm{GbE}$ has been reported to be effective against ischemic brain injury [32, 33], cerebral (or cerebrovascular) insufficiency [34], cognitive speed [35], dementia and Alzheimer's disease [36], peripheral vascular disease such as arterial occlusive disease [37], and aging damage [38]. In the case of renal cells, the GbE has renoprotective effect against cisplatin-induced nephrotoxicity [29]. In other study, changes in blood urea, serum creatinine, and creatinine clearance induced by gentamicin were significantly prevented by Ginkgo biloba extract [39]. Furthermore, the GbE diminishes adriamycin-induced proteinuria and hyperlipidaemic nephrotoxicity in rats [40].

Our hypothesis was that pretreatment with GbE as a single dose (10 mg/kg of body weight), administered intraperitoneally, would reverse the renal effects of the intravenous administration of a single dose of $\mathrm{TiO}_{2}-\mathrm{NPs}$, in the kidneys of adult male rats.

\section{Materials and Methods}

2.1. Animals and Reagents. Male adult Wistar rats (200$300 \mathrm{~g}$ ) were used and maintained in stainless steel cages with a $12 \mathrm{~h}$ light/dark regime. The rats were handled according to the Guiding Principles in the Use of Animals in Toxicology.

Ginkgo biloba extract was from Vasodil ${ }^{\oplus}$, NYCOMED, México, titanium dioxide nanoparticles were from Anatase, Sigma Aldrich, St. Louis, MO, USA, and $\gamma$-glutamyl pnitroanilide and gly-pro p-nitroanilide were from Sigma Aldrich, St. Louis, MO, USA.
2.2. Experimental Design. Treatment was as follows. The rats were divided into four groups: control group (treated with $5.0 \mathrm{mg} / \mathrm{kg}$ of sodium chloride aqueous solution, intravenously or i.v.), titanium dioxide group $\left(5.0 \mathrm{mg} / \mathrm{kg}\right.$ of $\mathrm{TiO}_{2}$, i.v.), Ginkgo biloba group (10 mg/kg, intraperitoneal or i.p.), and Ginkgo biloba + titanium dioxide group (treated $24 \mathrm{~h}$ before with $10 \mathrm{mg} / \mathrm{kg}$ of Ginkgo biloba extract, i.p.), followed, $24 \mathrm{~h}$ later, by $5.0 \mathrm{mg} / \mathrm{kg}$ of $\mathrm{TiO}_{2}$, i.p.

The rats were kept with food and water ad libitum and at room temperature $\left(24 \pm 1^{\circ} \mathrm{C}\right)$. The urine was continuously collected, in vessels attached to the metabolic cages, from 0 to $5 \mathrm{~h}$, from 5 to $24 \mathrm{~h}$, from 24 to $48 \mathrm{~h}$, and from 48 to $72 \mathrm{~h}$.

Biochemical assays were as follows. The specific activity of $\gamma$-glutamyltranspeptidase was determined in $50 \mathrm{mM}$ Tris$\mathrm{Cl}, \mathrm{pH} 9.0,10 \mathrm{mM} \mathrm{MgCl}$, with $20 \mathrm{mM}$ glycylglycine and $\gamma$-glutamyl p-nitroanilide as substrate, in a spectrophotometer at $405 \mathrm{~nm}$ [41]. The specific activity of dipeptidylaminopeptidase-IV was assayed in $50 \mathrm{mM}$ Tris-Cl, $\mathrm{pH}$ 8.0, with gly-pro p-nitroanilide as substrate, also at $405 \mathrm{~nm}$ [42] in a spectrophotometer. The enzymatic activities were carried out at room temperature $\left(25 \pm 1^{\circ} \mathrm{C}\right)$, in $0.5 \mathrm{~mL}$ final incubation volume. The initial enzymatic rates were calculated from continuous recording, usually in duplicates, in a Varian UV/VIS spectrophotometer (Varian DMS 80).

Protein was measured with the Folin phenol reagent using bovine serum albumin as standard [43]. We also measured in urine the volume, the concentration of creatinine [44], the $\mathrm{pH}$ in a $\mathrm{pH}$ meter, the osmolality in a microosmometer (Osmette, Precision Systems Model 5004), and the concentration of sodium in a flame photometer (Corning M410).

2.3. Statistical Analysis. We calculated the significance of the differences between group means with the two-tailed Student's $t$-test for grouped data with ANOVA posttest of the urinary parameters, using the software Prism 4 (GraphPad Software Inc.); graphs were produced using Slide Write Plus version 4.0 for Windows (Advanced Graphics Software Inc.).

\section{Results}

The pretreatment with a single and intraperitoneal dose of the Ginkgo biloba extract ( $\mathrm{GbE}$ ) reversed the renal effects of a single dose of $\mathrm{TiO}_{2}-\mathrm{NPs}$ ( $5 \mathrm{mg} / \mathrm{kg}$, intravenous), studied in the urine of adult male rats.

\subsection{The Effects of GbE on the Renal Effects of Titanium Dioxide $\left(\mathrm{TiO}_{2}\right)$ of the $\gamma$-Glutamyltranspeptidase Enzymatic Activity in Urine. The increased enzymatic activity of $\gamma$ - glutamyltranspeptidase, generated by titanium dioxide, was totally and significantly $(P<0.05)$ reversed with the $24 \mathrm{~h}$ pretreatment of $\mathrm{GbE}$, from $64.4 \pm 10.7$ to $6.9 \pm 0.8(0-5 \mathrm{~h})$, from $63.3 \pm 9.6$ to $14.5 \pm 0.5(5-24 \mathrm{~h})$, from $40.9 \pm 0.6$ to $5.8 \pm 0.9$ $(24-48 \mathrm{~h})$, and from $48.3 \pm 3.4$ to $4.5 \pm 0.2 \mathrm{nmol} \mathrm{pNA} / \mathrm{min} \times$ $\mathrm{mg}$ of protein (48-72 h), as shown in Figure 1.}

3.2. The Effects of GbE on the Renal Effects of Titanium Dioxide on the Enzymatic Activity of Urinary Dipeptidylaminopeptidase $I V$. The GbE partially and significantly $(P<0.05)$ 


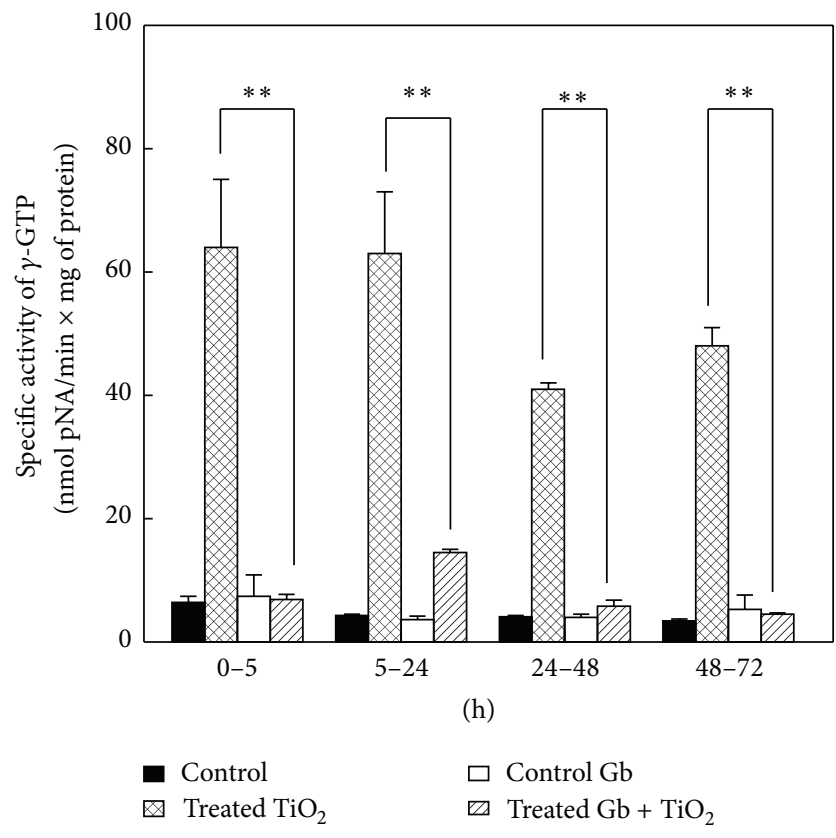

FIGURE 1: The effects of GbE on the renal effects of titanium dioxide $\left(\mathrm{TiO}_{2}\right)$ of the $\gamma$-glutamyltranspeptidase enzymatic activity in urine, at different time periods, compared with control, $\mathrm{GbE}$, and $\mathrm{TiO}_{2}$ treated rats. The enzymatic activity is shown as nmol p-NA/min $\times \mathrm{mg}$ of protein. The values represent mean \pm SEM, $n=6$. The significance level is ${ }^{* *} P<0.01$; pNA: p-nitroanilide.

reversed the increase on enzymatic activity of dipeptidylaminopeptidase IV, produced by $\mathrm{TiO}_{2}$, from $11.1 \pm 0.9$ to $4.0 \pm 0.3(0-5 \mathrm{~h})$, from $9.8 \pm 0.5$ to $6.7 \pm 0.7(5-24 \mathrm{~h})$, from $8.1 \pm 0.7$ to $2.8 \pm 0.1(24-48 \mathrm{~h})$, and from $8.5 \pm 0.3$ to $2.1 \pm$ $0.1 \mathrm{nmol} \mathrm{pNA} / \mathrm{min} \times \mathrm{mg}$ of protein $(48-72 \mathrm{~h})$, as depicted in Figure 2 .

3.3. The Effects of GbE on the Renal Effects of $\mathrm{TiO}_{2}$ of the Glucose Concentration in Urine. Figure 3 shows that the $\mathrm{GbE}$ decreased significantly $(P<0.05)$ the glucosuria, produced by titanium dioxide, only at 5 to $24 \mathrm{~h}(29.2 \pm 3.2$ to $2.5 \pm 0.2)$, and again from 48 to $72 \mathrm{~h}(19.1 \pm 3.5$ to $4.8 \pm 0.6 \mathrm{mg} / \mathrm{dL})$. The values from 24 to $48 \mathrm{~h}$ were not significantly different that control or GbE-treated rats.

3.4. The Effects of GbE on the Renal Effects of $\mathrm{TiO}_{2}$ of the Urinary Sodium Concentration. In Figure 4 it is shown that the GbE decreased significantly $(P<0.05)$ the hypernatruria produced by titanium dioxide: from 5 to $24 \mathrm{~h}(85 \pm 17$ to $49 \pm 9$ ), from 24 to $48 \mathrm{~h}(104 \pm 9$ to $63 \pm 5)$, and from 48 to $72 \mathrm{~h}(126 \pm 8$ to $73 \pm 5 \mathrm{mEq} / \mathrm{L})$.

\subsection{The Effects of GbE on the Renal Effects of Titanium Dioxide} in the Urine Osmolarity. The GbE diminished significantly $(P<0.05)$ the urinary hyperosmolarity produced by $\mathrm{TiO}_{2}$ only from $5-24 \mathrm{~h}(580 \pm 19$ to $272 \pm 69)$ and again from 48 to $72 \mathrm{~h}(516 \pm 7$ to $357 \pm 20 \mathrm{mOsmol} / \mathrm{L})$, as depicted in Figure 5 . The values from 24 to $48 \mathrm{~h}$ were not significantly different that control or GbE-treated rats.

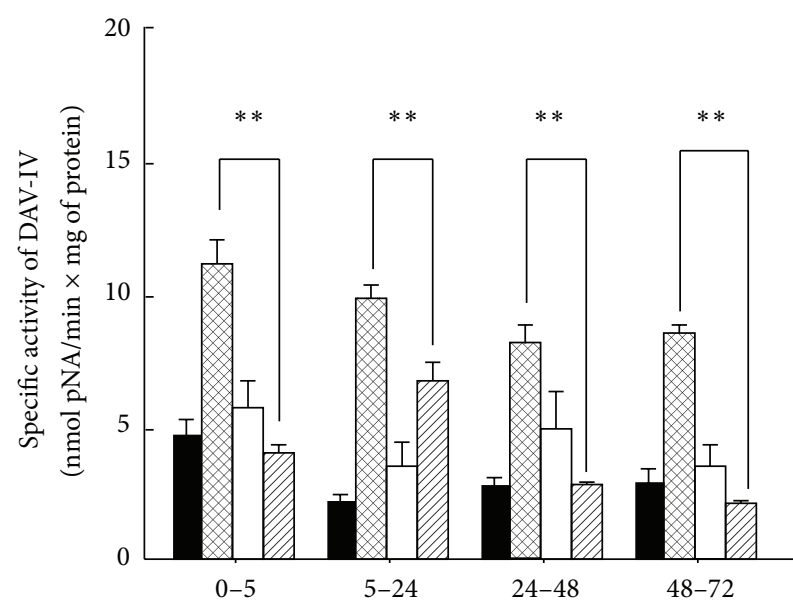

(h)

$$
\begin{array}{ll}
\text { Control } & \square \text { Control Gb } \\
\otimes \text { Treated } \mathrm{TiO}_{2} & \square \text { Treated } \mathrm{Gb}+\mathrm{TiO}_{2}
\end{array}
$$

FIGURE 2: The effects of GbE on the renal effects of titanium dioxide on the enzymatic activity of urinary dipeptidylaminopeptidase IV, at different time periods, compared with control, $\mathrm{GbE}$, and $\mathrm{TiO}_{2}$ treated rats. The enzymatic activity is shown as $\mathrm{nmol} \mathrm{p}-\mathrm{NA} / \mathrm{min}$ $\times \mathrm{mg}$ of protein. The values represent mean \pm SEM, $n=6$. The significance level is ${ }^{* *} P<0.01$; pNA: p-nitroanilide.

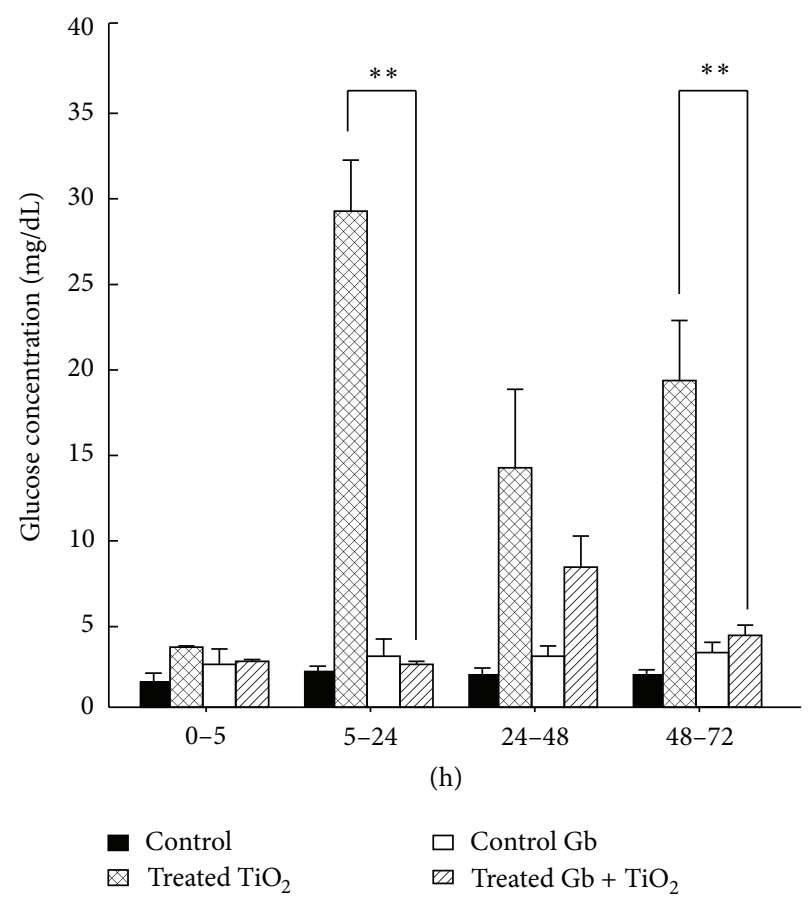

FIgure 3: The effects of GbE on the renal effects of $\mathrm{TiO}_{2}$ of the glucose concentration in urine, at different time periods, compared with control, $\mathrm{GbE}$, and $\mathrm{TiO}_{2}$-treated rats. The glucose concentration is presented as $\mathrm{mg} / \mathrm{dL}$. The significance level is ${ }^{* *} P<0.01$. 




(h)

$$
\begin{array}{ll}
\text { - Control } & \square \text { Control Gb } \\
\otimes \text { Treated } \mathrm{TiO}_{2} & \square \text { Treated Gb+ } \mathrm{TiO}_{2}
\end{array}
$$

FIgUre 4: The effects of GbE on the renal effects of $\mathrm{TiO}_{2}$ of the urinary sodium concentration, at different time periods, compared with control, $\mathrm{GbE}$, and $\mathrm{TiO}_{2}$-treated rats. The sodium concentration is presented as mEquivalents of $\mathrm{Na}^{+} /$liter. The significance levels are: ${ }^{*} P<0.05,{ }^{* *} P<0.01$.

\subsection{The Effects of GbE and Titanium Dioxide on Other Urinary} Parameters. Finally, the GbE alone did not significantly modify the concentrations of protein and creatinine, the volume, or the $\mathrm{pH}$ of urine, respectively, compared to control or GbE-pretreated rats, as shown in Table 1. Likewise, the GbE did not significantly modify the water and food intakes or the body weight, respectively, also compared to control or GbEpretreated rats, as depicted in Table 2 .

In Figure 6, we show a scheme about the possible mechanisms of the GbE polyphenols to protect the cytoplasmic membrane from renal effects produced by the titanium dioxide nanoparticles, at the luminal side of the brush border cells, all along the renal tubules of rat kidneys.

\section{Discussion}

The administration of a single and intraperitoneal dose of the Ginkgo biloba extract (GbE, $10 \mathrm{mg} / \mathrm{kg}$ of body weight) significantly $(>0.05)$ reversed the renal effects of a single and intravenous dose $(5 \mathrm{mg} / \mathrm{kg})$ of titanium dioxide $\left(\mathrm{TiO}_{2}\right)$ nanoparticles, studied in the urine of adult male rats. The dose of $\mathrm{TiO}_{2}$ that we used is 11.8 times lower than its $\mathrm{LD}_{50}$ [45]. $\mathrm{TiO}_{2}$-NPs are a fine white powder, often used as pigments or additives for ceramics, paints, paper, plastics, food, sunscreens, and toothpaste [46]. Living organisms are exposed to $\mathrm{TiO}_{2}$-NPs and may develop toxic effects. The toxicity of $\mathrm{TiO}_{2}$-NPs has mainly been studied in vitro [4750] but with fewer studies in vivo [51] and a growing need for in vivo research on the effects of nanoparticles $[52,53]$.



FIGURE 5: The effects of GbE on the renal effects of titanium dioxide in the urine osmolarity, at different time periods, compared with control, GbE, and $\mathrm{TiO}_{2}$-treated rats. The osmolarity is shown as mOsmoles/liter. The significance level is ${ }^{* *} P<0.01$.

Ginkgo biloba is one of the most widely used herbal remedies in Europe and US [54]. It is well known that the GbE contains $27 \%$ of the polyphenols isorhamnetin, kaempferol, and quercetin [24-27].

We believe that the renoprotective effects of the GbE, against the effects of $\mathrm{TiO}_{2}$ nanoparticles, are mainly due to the higher content and the interaction of the three $\mathrm{GbE}$ polyphenols with the cytoplasmic membrane of the brush border cells on the renal tubules and perhaps also to a synergistic effect among them.

The polyphenols interact with model membranes [55-67] and with erythrocyte membranes [68-70]. Some of the previous authors report evidence that this interaction is mainly due to hydrogen bonding between lipid polar head groups of membranes and the hydroxyl groups of polyphenols. This interaction would stabilize the membranes and influence their fluidity by decreasing packing in the hydrophilic region of membrane.

In relation to the specific activity of $\gamma$-glutamyltranspeptidase ( $\gamma$-GTP) and dipeptidylaminopeptidase IV (DAPIV), because they are in contact with the lumen of the renal tubules, and due to their location in the brush border membrane of renal proximal tubules $[13,14]$, they are the most susceptible parameters to the direct adverse effect by $\mathrm{TiO}_{2}$-NPs, and thus, they are the most benefited by the $\mathrm{GbE}$ at all times tested. This can be explained because the polyphenols exert a screen effect combined with its chelating and antioxidant activity. These properties have been well studied in quercetin $[71,72]$. 


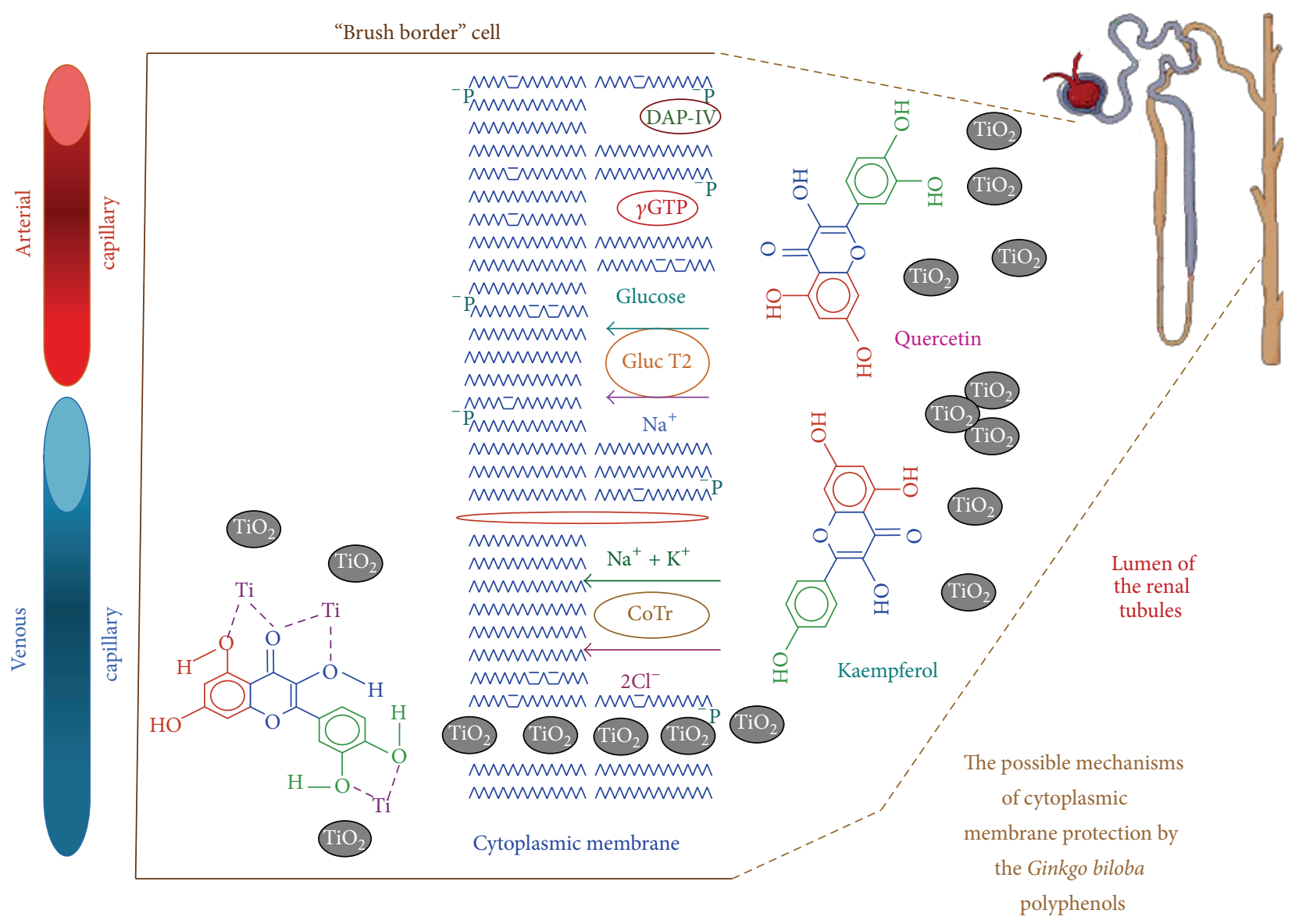

FIGURE 6: Scheme on the possible mechanisms of the GbE polyphenols for the renoprotection of the cytoplasmic membrane against the effects generated by the $\mathrm{TiO}_{2}$ nanoparticles, at the luminal side of the brush border cells, along the renal tubules of rat kidneys. $\gamma \mathrm{GT}$ : $\gamma$-glutamyltranspeptidase, DAP-IV: dipeptidylaminopeptidase IV, CoT: electroneutral Na-K-Cl cotransporter, and Gluc T2: Glucose-Na cotransporter 2 .

According to the other parameters, the time-related effects of $\mathrm{TiO}_{2}$-NPs were detected after the enzymuria, as increased concentration of the urinary glucose (glucosuria) and increased concentration of the urinary sodium (hypernatriuria), along with increased of urine osmolality. Similarly, with its polyphenols, the GbE exerted its beneficial mentioned properties $[71,72]$, protecting and preventing a dysregulation in the function of nephron cotransporters involved in the regulation of sodium, glucose, and therefore the osmolarity, produced by the $\mathrm{TiO}_{2}$-NPs.

Likewise, it is possible that the $\mathrm{GbE}$ renoprotection is potentiated by its components as reported in vivo for their pharmacokinetics in rats [73] and for the treatment of cancer [74-76]. We also believe that the polyphenols of the GbE participate, as antioxidants [77], in the renoprotective effects against $\mathrm{TiO}_{2}$, mainly at later times [78].

We do not rule out the participation of the antioxidant effects of GbE components on the renal effects like oxidative stress, generated by nanoparticles, reported by several authors [55, 79-82].
Finally, we could not find significant differences among the control, the $\mathrm{GbE}$, and the $\mathrm{TiO}_{2}$-treated rats for the following urinary parameters: the volume, the concentration of protein, the concentration of creatinine, or the $\mathrm{pH}$. Likewise, the water and food intakes as well as the gain in body weight were not statistically different in control rats, compared with the $\mathrm{GbE}$, and the $\mathrm{TiO}_{2}$-treated rats.

\section{Conclusions}

The administration of Ginkgo biloba extract (GbE, $10 \mathrm{mg} / \mathrm{kg}$ of body weight) by the intraperitoneal route and as a single dose reversed the renal effects of a single and intravenous dose $(5 \mathrm{mg} / \mathrm{kg})$ of titanium dioxide $\left(\mathrm{TiO}_{2}\right)$ nanoparticles in male and adult rats, studied in the urine. The GbE recovered the enzymatic activities of $\gamma$-glutamyltranspeptidase and of dipeptidylaminopeptidase IV. The GbE also reversed the glucosuria, the hypernatruria, and the hyperosmolarity generated by titanium dioxide. These effects appear to be mainly 
TABLE 1: The effects of the Ginkgo biloba extract $(10 \mathrm{mg} / \mathrm{kg}$ b.w., intraperitoneal) administered $24 \mathrm{~h}$ before titanium dioxide ( $5 \mathrm{mg} / \mathrm{kg}$ b.w., intravenous) on other urinary parameters studied.

\begin{tabular}{|c|c|c|c|c|}
\hline Parameter & $0-5 \mathrm{~h}$ & $5-24 \mathrm{~h}$ & $24-48 \mathrm{~h}$ & $48-72 \mathrm{~h}$ \\
\hline \multicolumn{5}{|l|}{ Protein $(\mathrm{mg} / \mathrm{mL})$} \\
\hline Control & $4.5 \pm 0.3$ & $8.8 \pm 0.4$ & $8.2 \pm 0.2$ & $8.8 \pm 0.2$ \\
\hline Control Gb & $6.8 \pm 2.2$ & $7.5 \pm 1.8$ & $10.7 \pm 0.8$ & $8.2 \pm 0.8$ \\
\hline Treated $\mathrm{TiO}_{2}$ & $5.3 \pm 0.5$ & $5.6 \pm 0.3$ & $6.9 \pm 0.3$ & $7.8 \pm 0.1$ \\
\hline Pretreated Gb & $6.9 \pm 0.3$ & $6.6 \pm 1.5$ & $8.3 \pm 0.2$ & $7.3 \pm 0.2$ \\
\hline \multicolumn{5}{|c|}{ Total creatinine $(\mathrm{mg} / \mathrm{dL})$} \\
\hline Control & $57 \pm 2.1$ & $87 \pm 1.7$ & $77 \pm 2.7$ & $62 \pm 5.1$ \\
\hline Control Gb & $46 \pm 6.9$ & $67 \pm 12.8$ & $68 \pm 1.9$ & $55 \pm 3.9$ \\
\hline Treated $\mathrm{TiO}_{2}$ & $47 \pm 1.5$ & $77 \pm 1.3$ & $83 \pm 0.6$ & $84 \pm 6.5$ \\
\hline Pretreated Gb & $47 \pm 7.9$ & $56 \pm 6.3$ & $63 \pm 2.2$ & $50 \pm 1.7$ \\
\hline \multicolumn{5}{|l|}{ Volume (mL) } \\
\hline Control & $4.0 \pm 0.5$ & $8.7 \pm 0.7$ & $8.7 \pm 0.5$ & $13.7 \pm 1.4$ \\
\hline Control Gb & $2.5 \pm 0.2$ & $8.0 \pm 2$ & $7.0 \pm 1.3$ & $7.0 \pm 0.9$ \\
\hline Treated $\mathrm{TiO}_{2}$ & $3.0 \pm 0.15$ & $9.0 \pm 1.0$ & $9.0 \pm 1.0$ & $9.0 \pm 1.0$ \\
\hline Pretreated Gb & $2.6 \pm 0.2$ & $10 \pm 2$ & $10 \pm 1$ & $11 \pm 1$ \\
\hline \multicolumn{5}{|l|}{$\mathrm{pH}$} \\
\hline Control & $7.6 \pm 0.2$ & $7.4 \pm 0.3$ & $7.3 \pm 0.3$ & $6.9 \pm 0.4$ \\
\hline Control Gb & $8.0 \pm 0.05$ & $7.0 \pm 0.5$ & $6.5 \pm 0.2$ & $7.8 \pm 0.1$ \\
\hline Treated $\mathrm{TiO}_{2}$ & $6.5 \pm 0.3$ & $6.5 \pm 0.3$ & $6.8 \pm 0.2$ & $6.3 \pm 0.2$ \\
\hline Pretreated Gb & $7.0 \pm 0.3$ & $7.8 \pm 0.2$ & $7.8 \pm 0.2$ & $7.7 \pm 0.2$ \\
\hline
\end{tabular}

Values represent mean $\pm \operatorname{SEM}(n=6)$.

TABLE 2: The effects of the Ginkgo biloba extract ( $10 \mathrm{mg} / \mathrm{kg}$ b.w., intraperitoneal) administered $24 \mathrm{~h}$ before titanium dioxide ( $5 \mathrm{mg} / \mathrm{kg}$ b.w., intravenous) on general parameters studied.

\begin{tabular}{|c|c|c|c|}
\hline Parameter & $5-24 \mathrm{~h}$ & $24-48 \mathrm{~h}$ & $48-72 \mathrm{~h}$ \\
\hline \multicolumn{4}{|c|}{ Water consumption ( $\mathrm{mL}$ in 19 or $24 \mathrm{~h}$ ) } \\
\hline Control & $35 \pm 3.4$ & $32 \pm 3.1$ & $35 \pm 1.9$ \\
\hline Control Gb & $23 \pm 5.0$ & $42 \pm 7.2$ & $32 \pm 5.2$ \\
\hline Treated $\mathrm{TiO}_{2}$ & $35 \pm 5.1$ & $32 \pm 4.1$ & $30 \pm 4.1$ \\
\hline Pretreated Gb & $25 \pm 3.3$ & $38 \pm 2.4$ & $33 \pm 2.2$ \\
\hline \multicolumn{4}{|c|}{ Food consumption ( $\mathrm{g}$ in 19 or $24 \mathrm{~h}$ ) } \\
\hline Control & $18 \pm 1.3$ & $19 \pm 0.7$ & $21 \pm 1.4$ \\
\hline Control Gb & $14 \pm 1.5$ & $14 \pm 5.1$ & $12 \pm 4.1$ \\
\hline Treated $\mathrm{TiO}_{2}$ & $19 \pm 1.1$ & $16 \pm 1.3$ & $15 \pm 1.4$ \\
\hline Pretreated Gb & $18 \pm 1.2$ & $17 \pm 1.4$ & $17 \pm 1.2$ \\
\hline \multicolumn{4}{|c|}{ Body weight ( $\mathrm{g}$ in 19 or $24 \mathrm{~h}$ ) } \\
\hline Control & $305 \pm 10$ & $302 \pm 10$ & $299 \pm 11$ \\
\hline Control Gb & $282 \pm 24$ & $280 \pm 18$ & $269 \pm 23$ \\
\hline Treated $\mathrm{TiO}_{2}$ & $227 \pm 13$ & $237 \pm 14$ & $246 \pm 16$ \\
\hline Pretreated Gb & $278 \pm 13$ & $270 \pm 16$ & $273 \pm 33$ \\
\hline
\end{tabular}

Values represent mean $\pm \operatorname{SEM}(n=6)$.

due to the interaction and protection of the GbE polyphenols with the cytoplasmic membrane on renal tubules of the male adult rats. Thus, we conclude that GbE has a beneficial activity in the cytoplasmic membranes of brush border cells on the renal tubules, against the adverse effects that can be produced by some xenobiotics, in this case the $\mathrm{TiO}_{2}-\mathrm{NPs}$, in experimental rats. Therefore, our research highlights the pharmacological activity of the Ginkgo biloba extract, which can be used as an alternative treatment to protect renal cells against the toxicity produced by $\mathrm{TiO}_{2}$-NPs.

\section{Conflict of Interests}

The authors acknowledge that there is no conflict of interests.

\section{Acknowledgments}

The authors acknowledge the doctoral fellowship to Carlos Enrique Escárcega-González (CONACYT-CVU: 377051) and the research funding for their Academic Group from PROMEP-SEP (UAA CA25) to the Universidad Autónoma de Aguascalientes.

\section{References}

[1] G. Giebish and E. Windhager, "Organization of the urinary system," in Medical Physiology, W. F. Boron and E. L. Boulpaep, Eds., pp. 747-766, Saunders, Elsevier Science, Philadelphia, Pa, USA, 2008.

[2] W. Feng, B. Wang, and Y. Zhao, "Nanotoxicity of metal oxide nanoparticles in vivo," in Nanotoxicity, S. C. Sahu and D. A. Casciano, Eds., chapter 13, pp. 247-269, John Wiley \& Sons, Chichester, UK, 2009.

[3] H. Shi, R. Magaye, V. Castranova, and J. Zhao, "Titanium dioxide nanoparticles: a review of current toxicological data," Particle and Fibre Toxicology, vol. 10, no. 1, article 15, 2013.

[4] A. A. Shvedova, V. E. Kagan, and B. Fadeel, "Close encounters of the small kind: adverse effects of man-made materials interfacing with the nano-cosmos of biological systems," Annual Review of Pharmacology and Toxicology, vol. 50, pp. 63-88, 2010.

[5] S. Barillet, A. Simon-Deckers, N. Herlin-Boime et al., "Toxicological consequences of $\mathrm{TiO}_{2}, \mathrm{SiC}$ nanoparticles and multiwalled carbon nanotubes exposure in several mammalian cell types: an in vitro study, Journal of Nanoparticle Research, vol. 12, no. 1, pp. 61-73, 2010.

[6] B. L'Azou, J. Jorly, D. On et al., "In vitro effects of nanoparticles on renal cells," Particle and Fibre Toxicology, vol. 5, article 22, 2008.

[7] I. Pujalté, I. Passagne, B. Brouillaud et al., "Cytotoxicity and oxidative stress induced by different metallic nanoparticles on human kidney cells," Particle and Fibre Toxicology, vol. 8, article 10, 2011.

[8] K. Šebeková, M. Dušinská, K. Simon Klenovics et al., “Comprehensive assessment of nephrotoxicity of intravenously administered sodium-oleate-coated ultra-small superparamagnetic iron oxide (USPIO) and titanium dioxide $\left(\mathrm{TiO}_{2}\right)$ nanoparticles in rats," Nanotoxicology, vol. 8, no. 2, pp. 142-157, 2014.

[9] H. Shi, R. Magaye, V. Castranova, and J. Zhao, "Titanium dioxide nanoparticles: a review of current toxicological data," Particle and Fibre Toxicology, vol. 10, article 15, 2013.

[10] E. Fabian, R. Landsiedel, L. Ma-Hock, K. Wiench, W. Wohlleben, and B. van Ravenzwaay, "Tissue distribution and toxicity of intravenously administered titanium dioxide nanoparticles in rats," Archives of Toxicology, vol. 82, no. 3, pp. 151-157, 2008.

[11] J. Wang, G. Zhou, C. Chen et al., "Acute toxicity and biodistribution of different sized titanium dioxide particles in mice after 
oral administration," Toxicology Letters, vol. 168, no. 2, pp. 176185, 2007.

[12] W. E. Stroo and J. B. Hook, "Enzymes of renal origin in urine as indicators of nephrotoxicity," Toxicology and Applied Pharmacology, vol. 39, no. 3, pp. 423-434, 1977.

[13] W. G. Guder and B. D. Ross, "Enzyme distribution along the nephron," Kidney International, vol. 26, no. 2, pp. 101-111, 1984.

[14] A. J. Kenny, A. G. Booth, S. G. George et al., "Dipeptidyl peptidase IV, a kidney brush-border serine peptidase," Biochemical Journal, vol. 157, no. 1, pp. 169-182, 1976.

[15] H.-J. Choi, Y.-J. Yoon, Y.-K. Kwon et al., "Patterns of gene and metabolite define the effects of extracellular osmolality on kidney collecting duct," Journal of Proteome Research, vol. 11, no. 7, pp. 3816-3828, 2012.

[16] A. M. Beer, "Herbal medicines used in kidney diseases in Europe," Iranian Journal of Kidney Diseases, vol. 5, no. 2, pp. 8285, 2011.

[17] T. E. Brinkley, J. F. Lovato, A. M. Arnold et al., "Effect of Ginkgo biloba on blood pressure and incidence of hypertension in elderly men and women," American Journal of Hypertension, vol. 23, no. 5, pp. 528-533, 2010.

[18] P.-C. Chan, Q. Xia, and P. P. Fu, "Ginkgo biloba leave extract: biological, medicinal, and toxicological effects," Journal of Environmental Science and Health Part C: Environmental Carcinogenesis and Ecotoxicology Reviews, vol. 25, no. 3, pp. 211-244, 2007.

[19] C. Culmsee and J. Krieglstein, "Ischaemic brain damage after stroke: new insights into efficient therapeutic strategies. International Symposium on Neurodegeneration and Neuroprotection," EMBO Reports, vol. 8, no. 2, pp. 129-133, 2007.

[20] H. P. Fransen, S. M. G. J. Pelgrom, B. Stewart-Knox, D. de Kaste, and H. Verhagen, "Assessment of health claims, content, and safety of herbal supplements containing Ginkgo biloba," Food \& Nutrition Research, vol. 54, article 5221, 2010.

[21] S. Mahadevan and Y. Park, "Multifaceted therapeutic benefits of Ginkgo biloba L.: chemistry, efficacy, safety, and uses," Journal of Food Science, vol. 73, no. 1, pp. R14-R19, 2008.

[22] L. L. Ponto and S. K. Schultz, "Ginkgo biloba extract: review of CNS effects," Annals of Clinical Psychiatry, vol. 15, no. 2, pp. 109119, 2003.

[23] Y. Zhang, X. Wang, L. Wang, M. Yu, and X. Han, "Interactions of the baicalin and baicalein with bilayer lipid membranes investigated by cyclic voltammetry and UV-Vis spectroscopy," Bioelectrochemistry, vol. 95, pp. 29-33, 2014.

[24] F. Deng and S. W. Zito, "Development and validation of a gas chromatographic-mass spectrometric method for simultaneous identification and quantification of marker compounds including bilobalide, ginkgolides and flavonoids in Ginkgo biloba L. extract and pharmaceutical preparations," Journal of Chromatography A, vol. 986, no. 1, pp. 121-127, 2003.

[25] M.-J. Dubber and I. Kanfer, "High-performance liquid chromatographic determination of selected flavonols in Ginkgo biloba solid oral dosage forms," Journal of Pharmacy and Pharmaceutical Sciences, vol. 7, no. 3, pp. 303-309, 2004.

[26] C.-Y. Li, C.-H. Lin, C.-C. Wu, K.-H. Lee, and T.-S. Wu, "Efficient ${ }^{1} \mathrm{H}$ nuclear magnetic resonance method for improved quality control analyses of Ginkgo constituents," Journal of Agricultural and Food Chemistry, vol. 52, no. 12, pp. 3721-3725, 2004.

[27] T. A. van Beek and P. Montoro, "Chemical analysis and quality control of Ginkgo biloba leaves, extracts, and phytopharmaceuticals," Journal of Chromatography A, vol. 1216, no. 11, pp. 20022032, 2009.
[28] X. Yao, G.-S. Zhou, Y.-P. Tang et al., "Simultaneous quantification of flavonol glycosides, terpene lactones, biflavones, proanthocyanidins, and ginkgolic acids in ginkgo biloba leaves from fruit cultivars by ultrahigh-performance liquid chromatography coupled with triple quadrupole mass spectrometry," BioMed Research International, vol. 2013, Article ID 582591, 11 pages, 2013.

[29] J. Song, D. Liu, L. Feng, Z. Zhang, X. Jia, and W. Xiao, "Protective effect of standardized extract of Ginkgo biloba against cisplatin-induced nephrotoxicity," Evidence-Based Complementary and Alternative Medicine, vol. 2013, Article ID 846126, 11 pages, 2013.

[30] W.-D. Chen, Y. Liang, L. Xie, T. Lu, X.-D. Liu, and G.-J. Wang, "Pharmacokintics of the Ginkgo Bfollowing intravenous administration of Ginkgo B emulsion in rats," Biological and Pharmaceutical Bulletin, vol. 30, no. 1, pp. 1-5, 2007.

[31] J. M. Cárdenas, M. C. Martínez, F. Jaramillo et al., "The protective effect of Ginkgo biloba on the damage induced by methyl parathion in cerebellar granule cells of rat," Revista Mexicana de Ciencias Farmacéuticas, vol. 41, no. 4, pp. 37-42, 2010.

[32] J. Kleijnen and P. Knipschild, "Ginkgo biloba for cerebral insufficiency," British Journal of Clinical Pharmacology, vol. 34, no. 4, pp. 352-358, 1992.

[33] W. R. Zhang, T. Hayashi, H. Kitagawa et al., "Protective effect of Ginkgo extract on rat brain with transient middle cerebral artery occlusion," Neurological Research, vol. 22, no. 5, pp. 517521, 2000.

[34] J. Vesper and K. D. Hänsgen, "Efficacy of Ginkgo biloba in 90 outpatients with cerebral insufficiency caused by old age: results of a placebo-controlled double-blind trial," Phytomedicine, vol. 1, no. 1, pp. 9-16, 1994.

[35] D. O. Kennedy, A. B. Scholey, and K. A. Wesnes, “The dosedependent cognitive effects of acute administration of Ginkgo biloba to healthy young volunteers," Psychopharmacology, vol. 151, no. 4, pp. 416-423, 2000.

[36] P. L. Le Bars, M. M. Katz, N. Berman, T. M. Itil, A. M. Freedman, and A. F. Schatzberg, "A placebo-controlled, double-blind, randomized trial of an extract of Ginkgo biloba for dementia," The Journal of the American Medical Association, vol. 278, no. 16, pp. 1327-1332, 1997.

[37] H. Peters, M. Kieser, and U. Hölscher, "Demonstration of the efficacy of ginkgo biloba special extract EGb 761 on intermittent claudication - a placebo-controlled, double-blind multicenter trial," European Journal of Vascular Medicine, vol. 27, no. 2, pp. 106-110, 1998.

[38] B. J. Diamond, S. C. Shiflett, N. Feiwel et al., "Ginkgo biloba extract: mechanisms and clinical indications," Archives of Physical Medicine and Rehabilitation, vol. 81, no. 5, pp. 668-678, 2000.

[39] M. U. R. Naidu, A. A. Shifow, K. V. Kumar, and K. S. Ratnakar, "Ginkgo biloba extract ameliorates gentamicin-induced nephrotoxicity in rats," Phytomedicine, vol. 7, no. 3, pp. 191-197, 2000.

[40] M. F. Abd-Ellah and A. D. Mariee, "Ginkgo biloba leaf extract (EGb 761) diminishes adriamycin-induced hyperlipidaemic nephrotoxicity in rats: association with nitric oxide production," Biotechnology and Applied Biochemistry, vol. 46, no. 1, pp. 35-40, 2007.

[41] M. Orlowski and A. Meister, " $\gamma$-Glutamyl-p-nitroanilide: a new convenient substrate for determination of L- and D$\gamma$-glutamyltranspeptidase activities," Biochimica et Biophysica Acta, vol. 73, pp. 679-681, 1963. 
[42] T. Yoshimoto, M. Fischl, R. C. Orlowski, and R. Walter, "Post-proline cleaving enzyme and post-proline dipeptidyl aminopeptidase. Comparison of two peptidases with high specificity for proline residues," The Journal of Biological Chemistry, vol. 253, no. 10, pp. 3708-3716, 1978.

[43] M. Jaffe, "Ueber den niederschlag, welchen Pikrinsäure in normalem Harn erzeugt und über eine neue reaction des Kreatinins," Biological Chemistry, vol. 10, no. 5, pp. 391-400, 1886.

[44] O. H. Lowry, N. J. Rosenbrough, A. L. Farr, and R. J. Randall, "Protein measurement with the Folin phenol reagent," The Journal of biological chemistry, vol. 193, no. 1, pp. 265-275, 1951.

[45] K. Volkovova, R. D. Handy, M. Staruchova et al., "Health effects of selected nanoparticles in vivo: liver function and hepatotoxicity following intravenous injection of titanium dioxide and Na-oleate-coated iron oxide nanoparticles in rodents," Nanotoxicology, vol. 9, supplement 1, pp. 95-105, 2015.

[46] X. Chen and S. S. Mao, "Titanium dioxide nanomaterials: synthesis, properties, modifications and applications," Chemical Reviews, vol. 107, no. 7, pp. 2891-2959, 2007.

[47] S. Arora, J. M. Rajwade, and K. M. Paknikar, "Nanotoxicology and in vitro studies: the need of the hour," Toxicology and Applied Pharmacology, vol. 258, no. 2, pp. 151-165, 2012.

[48] I. Iavicoli, V. Leso, L. Fontana, and A. Bergamaschi, “Toxicological effects of titanium dioxide nanoparticles: a review of in vitro mammalian studies," European Review for Medical and Pharmacological Sciences, vol. 15, no. 5, pp. 481-508, 2011.

[49] C. Jin, Y. Tang, F. G. Yang et al., "Cellular toxicity of $\mathrm{TiO}_{2}$ nanoparticles in anatase and rutile crystal phase," Biological Trace Element Research, vol. 141, no. 1-3, pp. 3-15, 2011.

[50] S. Smulders, K. Luyts, G. Brabants et al., "Toxicity of nanoparticles embedded in paints compared to pristine nanoparticles, in vitro study," Toxicology Letters, vol. 232, no. 2, pp. 333-339, 2015.

[51] S. Smulders, K. Luyts, G. Brabants et al., "Toxicity of nanoparticles embedded in paints compared with pristine nanoparticles in mice," Toxicological Sciences, vol. 141, no. 1, pp. 132-140, 2014.

[52] H. C. Fischer and W. C. Chan, "Nanotoxicity: the growing need for in vivo study," Current Opinion in Biotechnology, vol. 18, no. 6, pp. 565-571, 2007.

[53] I. Iavicoli, V. Leso, and A. Bergamaschi, "Toxicological effects of titanium dioxide nanoparticles: a review of in vivo studies," Journal of Nanomaterials, vol. 2012, Article ID 964381, 36 pages, 2012.

[54] A. Arora, T. M. Byrem, M. G. Nair, and G. M. Strasburg, "Modulation of liposomal membrane fluidity by flavonoids and isoflavonoids," Archives of Biochemistry and Biophysics, vol. 373, no. 1, pp. 102-109, 2000.

[55] T. Heinonen and W. Gaus, "Cross matching observations on toxicological and clinical data for the assessment of tolerability and safety of Ginkgo biloba leaf extract," Toxicology, vol. 327, no. 1, pp. 95-115, 2015.

[56] K. Cieślik-Boczula, J. Maniewska, G. Grynkiewicz, W. Szeja, A. Koll, and A. B. Hendrich, "Interaction of quercetin, genistein and its derivatives with lipid bilayers-an ATR IR-spectroscopic study," Vibrational Spectroscopy, vol. 62, pp. 64-69, 2012.

[57] A. B. Hendrich, "Flavonoid-membrane interactions: possible consequences for biological effects of some polyphenolic compounds," Acta Pharmacologica Sinica, vol. 27, no. 1, pp. 27-40, 2006.

[58] H. I. Ingólfsson, P. Thakur, K. F. Herold et al., "Phytochemicals perturb membranes and promiscuously alter protein function," ACS Chemical Biology, vol. 9, no. 8, pp. 1788-1798, 2014.
[59] J. Y. A. Lehtonen, H. Adlercreutz, and P. K. J. Kinnunen, "Binding of daidzein to liposomes," Biochimica et Biophysica Acta (BBA)-Biomembranes, vol. 1285, no. 1, pp. 91-100, 1996.

[60] K.-L. Liao and M.-C. Yin, "Individual and combined antioxidant effects of seven phenolic agents in human erythrocyte membrane ghosts and phosphatidylcholine liposome systems: importance of the partition coefficient," Journal of Agricultural and Food Chemistry, vol. 48, no. 6, pp. 2266-2270, 2000.

[61] F. Ollila, K. Halling, P. Vuorela, H. Vuorela, and J. P. Slotte, "Characterization of flavonoid-biomembrane interactions," Archives of Biochemistry and Biophysics, vol. 399, no. 1, pp. 103-108, 2002.

[62] P. I. Oteiza, A. G. Erlejman, S. V. Verstraeten, C. L. Keen, and C. G. Fraga, "Flavonoid-membrane interactions: a protective role of flavonoids at the membrane surface?" Clinical and Developmental Immunology, vol. 12, no. 1, pp. 19-25, 2005.

[63] B. Pawlikowska-Pawlega, L. E. Misiak, B. Zarzyka et al., "Modification of membranes by quercetin, a naturally occurring flavonoid, via its incorporation in the polar head group," $B B A-$ Biomembranes, vol. 1768, no. 9, pp. 2195-2204, 2007.

[64] B. Pawlikowska-Pawlęga, L. E. Misiak, B. Zarzyka, R. Paduch, A. Gawron, and W. I. Gruszecki, "Localization and interaction of genistein with model membranes formed with dipalmitoylphosphatidylcholine (DPPC)," Biochimica et Biophysica Acta (BBA)_Biomembranes, vol. 1818, no. 7, pp. 1785-1793, 2012.

[65] M. Raghunathan, Y. Zubovski, R. M. Venable, R. W. Pastor, J. F. Nagle, and S. Tristram-Nagle, "Structure and elasticity of lipid membranes with genistein and daidzein bioflavinoids using Xray scattering and MD simulations," The Journal of Physical Chemistry B, vol. 116, no. 13, pp. 3918-3927, 2012.

[66] H. A. Scheidt, A. Pampel, L. Nissler, R. Gebhardt, and D. Huster, "Investigation of the membrane localization and distribution of flavonoids by high-resolution magic angle spinning NMR spectroscopy," Biochimica et Biophysica Acta (BBA)Biomembranes, vol. 1663, no. 1-2, pp. 97-107, 2004.

[67] H. Tsuchiya, M. Nagayama, T. Tanaka, M. Furusawa, M. Kashimata, and H. Takeuchi, "Membrane-rigidifying effects of anti-cancer dietary factors," BioFactors, vol. 16, no. 3-4, pp. 4556, 2002.

[68] V. Ajdžanović, I. Spasojević, B. Filipović, B. Šošić-Jurjević, M. Sekulić, and V. Miloševic, "Effects of genistein and daidzein on erythrocyte membrane fluidity: an electron paramagnetic resonance study," Canadian Journal of Physiology and Pharmacology, vol. 88, no. 4, pp. 497-500, 2010.

[69] S. Cyboran, J. Oszmiański, and H. Kleszczyńska, "Interaction between plant polyphenols and the erythrocyte membrane," Cellular and Molecular Biology Letters, vol. 17, no. 1, pp. 77-88, 2012.

[70] B. Pawlikowska-Pawlęga, W. I. Gruszecki, L. E. Misiak, and A. Gawron, "The study of the quercetin action on human erythrocyte membranes," Biochemical Pharmacology, vol. 66, no. 4, pp. 605-612, 2003.

[71] S. Fiorucci, J. Golebiowski, D. Cabrol-Bass, and S. Antonczak, "DFT study of quercetin activated forms involved in antiradical, antioxidant, and prooxidant biological processes," Journal of Agricultural and Food Chemistry, vol. 55, no. 3, pp. 903-911, 2007.

[72] H. Paulíková and E. Berczeliová, "The effect of quercetin and galangin on glutathione reductase," Biomedical Papers of Medical Faculty of University Palacky Olomouc Czech Republic, vol. 149, no. 2, pp. 497-500, 2005. 
[73] H. Guan, D. Qian, H. Ren et al., "Interactions of pharmacokinetic profile of different parts from Ginkgo biloba extract in rats," Journal of Ethnopharmacology, vol. 155, no. 1, pp. 758-768, 2014.

[74] R. H. Liu, "Potential synergy of phytochemicals in cancer prevention: mechanism of action," Journal of Nutrition, vol. 134, no. 12, pp. 3479S-3485S, 2004.

[75] Y. Yang, Z. Zhang, S. Li, X. Ye, X. Li, and K. He, "Synergy effects of herb extracts: pharmacokinetics and pharmacodynamic basis," Fitoterapia, vol. 92, no. 2, pp. 133-147, 2014.

[76] H. Wagner, "Synergy research: approaching a new generation of phytopharmaceuticals," Fitoterapia, vol. 82, no. 1, pp. 34-37, 2011.

[77] B. Pahari, S. Chakraborty, S. Chaudhuri, B. Sengupta, and P. K. Sengupta, "Binding and antioxidant properties of therapeutically important plant flavonoids in biomembranes: insights from spectroscopic and quantum chemical studies," Chemistry and Physics of Lipids, vol. 165, no. 4, pp. 488-496, 2012.

[78] C. E. Escárcega-González, Estudio de la toxicidad de nanopartículas de $\mathrm{TiO}_{2}$ y $\mathrm{TiO}_{2} / \mathrm{Ag}$ en ratas wistar machos [Thesis for Master in Science (Toxicology)], Departamento de Farmacología y Fisiología y Departamento de Departamento de Química. Centro de Ciencias Básicas, Universidad Autónoma de Aguascalientes, Aguascalientes, México, 2012.

[79] H. M. Bolt, R. Marchan, and J. G. Hengstler, "Nanotoxicology and oxidative stress control: cutting-edge topics in toxicology," Archives of Toxicology, vol. 86, no. 11, pp. 1629-1635, 2012.

[80] M. E. Bruno, D. R. Tasat, E. Ramos et al., "Impact through time of different sized titanium dioxide particles on biochemical and histopathological parameters," Journal of Biomedical Materials Research Part A, vol. 102, no. 5, pp. 1439-1448, 2014.

[81] B. Halamoda Kenzaoui, C. Chapuis Bernasconi, and L. JuilleratJeanneret, "Stress reaction of kidney epithelial cells to inorganic solid-core nanoparticles," Cell Biology and Toxicology, vol. 29, no. 1, pp. 39-58, 2013.

[82] S. Hussain, S. Boland, A. Baeza-Squiban et al., "Oxidative stress and proinflammatory effects of carbon black and titanium dioxide nanoparticles: role of particle surface area and internalized amount," Toxicology, vol. 260, no. 1-3, pp. 142-149, 2009. 

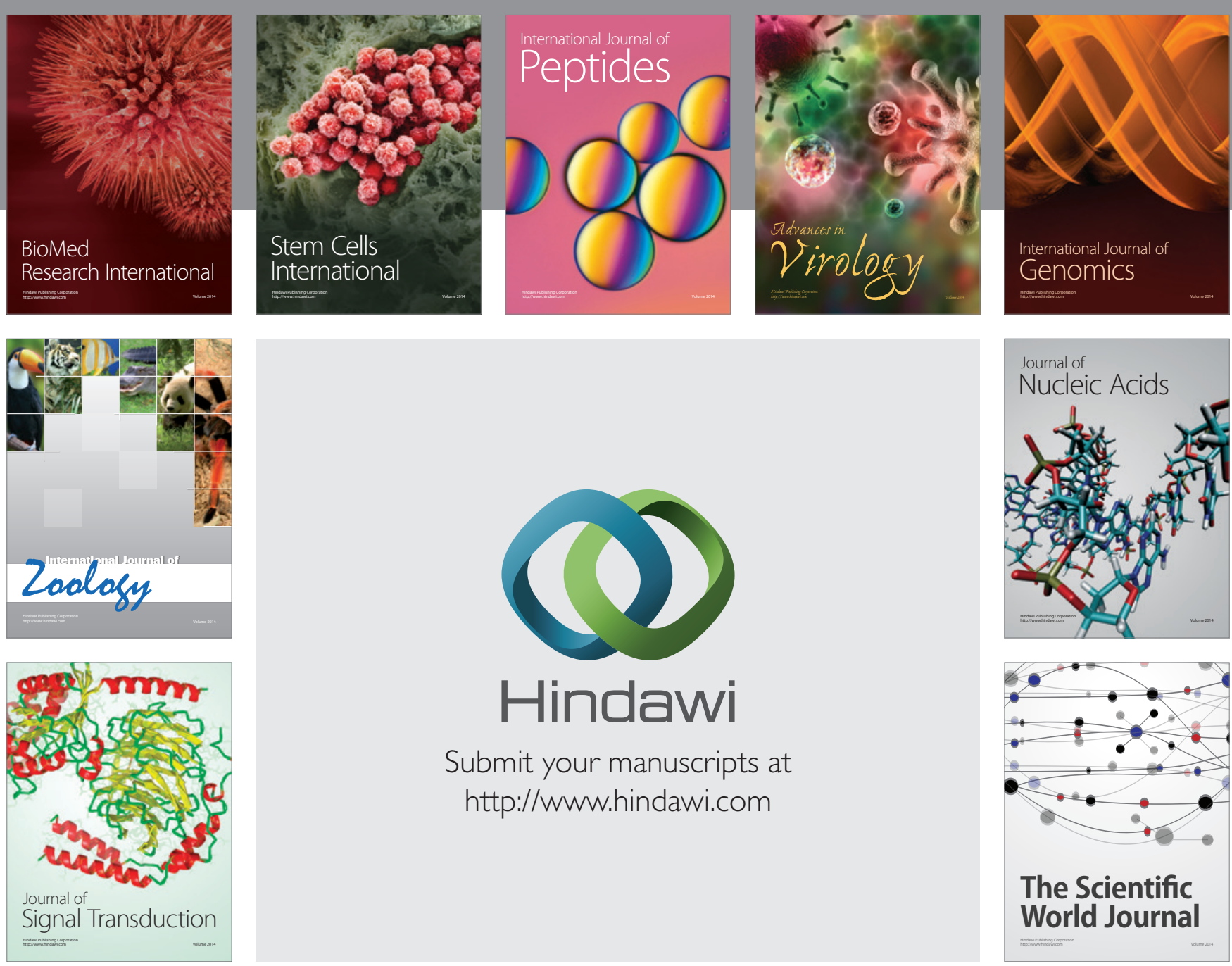

Submit your manuscripts at

http://www.hindawi.com
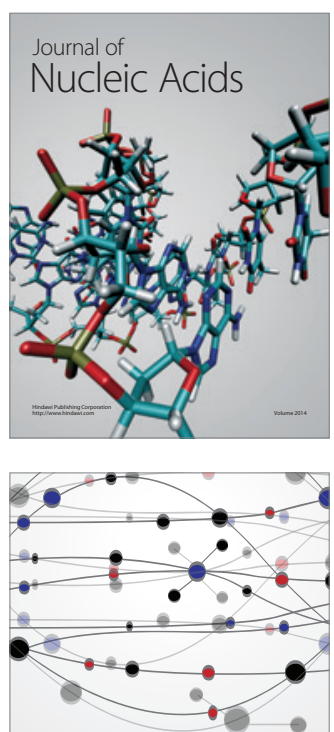

The Scientific World Journal
